\title{
Islamic Revolution of Iran and Political Development Issue (1997-2005)
}

\author{
Kamran Rahmani ${ }^{1} \&$ Alireza Azghandi ${ }^{2}$ \\ ${ }^{1} \mathrm{PhD}$ Student of Political Science, Department of Political Science, Faculty of Low and Politics, Science and \\ Research Branch, Islamic Azad University, Tehran, Iran \\ ${ }^{2}$ Full Professor of Department of Political Science, Faculty of Law and Politics, Science and Research Branch, \\ Islamic Azad University, Tehran, Iran \\ Correspondence: Alireza Azghandi, Full Professor of Department of Political Science, Faculty of Law and \\ Politics, Science and Research Branch, Islamic Azad University, Tehran, Iran. E-mail: Sayekam@yahoo.com
}

Received: August 16, 2016 Accepted: September 14, 2016 Online Published: November 30, 2016

doi:10.5539/jpl.v9n10p31 URL: http://dx.doi.org/10.5539/jpl.v9n10p31

\begin{abstract}
The theories of Political Development introduced broadly in political studies at the sometime with ending World War II and releasing the third world countries from colonialism. After a long evolution process, the literature and the concept of Political Development declined to democracy. Such an evolution has been along with an increasing trend of democracy in developing countries. During the last century in Iran, a numerous thinking movements have been introduced about this issue. Currently, this question is what achievements have Islamic revolution of Iran according to political aspect and what policies and plans have been used for their goals? The findings of this research show that governments have chosen different approaches after forming and stabilization of Islamic Republic of Iran. The Results also showed that the governments followed their different plans and policies; however, with regards to relative distance of governments approaches with revolution goals, there are many capacities to accomplish political development in Iran. In general, it can be concluded that the Political Development as the focus of reformist thinking has structural and legal challenges (outer barriers). Furthermore, a systematic concept and definition was not presented among the reformist (inner barriers), and mechanisms and indicators of political development were not identified.
\end{abstract}

Keywords: revolution, political development, reforms, religious democracy, reformists, law-orientation

\section{Introduction}

The political development is a product of revolutions after the Word War II. The political development theories were adopted from the west development theories and based on European and US experiences as the worldwide vale transferred to the third world countries. Therefore, the full aspect of political development was not anything except west democracy (Badii', 2008: 11) and political development means simulation of west and the third world countries as the type of evolution from traditional to modern society while goal is reaching liberal democracy. In this model, development theories can be prescribed s generalizable models besides determination the claim. However, since late 1960s, the public theory suggestion was omitted and considering certain conditions, features, and differentiations of the third world was considered. Therefore, scholars have seeks to find a specific development model for the third world countries by historical and sociological studies. Hence, the development-orientation dominance and worldwide thoughts were finished and instead discovering unique social phenomena and related cultural analysis of these phenomena were considered.

Undoubtedly, reaching liberty and justice is the inseparable objective of all revolutions. In Iran, there is a long history of struggles and demands of seeking to eliminate tyranny, as this campaign continues. In spite of affluent attempts to reach liberty, equality, autonomy, prosperity, and security, there are still dispute over political changes and structural reforms towards democratization, as well as the opportunities and challenges in the great constitutional movement, the national movement and the Islamic Revolution of the oil industry in 1978. After Jun, 1997 the political atmosphere became relatively varied by the main slogan of political reform movement.

Actually, people polling behavior in May, 23, 1997, that was one of great and unique representation of people civilization participation to state the main design, and actually explicit objection to the present condition at that 
time so made evolutions in Iran ascending related issues to political development mechanisms. Generally, after May, 23, 1997, the political development concept was focused by political discourses and views and led to pervasive requisitions design (liberty, law, pluralism, free press, independent and free activity of political parties and people's sovereignty over their fate and their involvement in decision-making). Reformism stream and actually its theorists and leaders proposed a thought could be hegemonic dominant in spite of the subjects, coherence and theoretical content, regardless of its relevance or non-relevance with Iran. The main question of this article is what are the main obstacles of political development in Iran after its serious proposing in May, 23, 1997 as the main objective of reformisms tam according to political development issues in Iran? Actually, it is tried to answer the obstacles by emphasis on internal problems and pathology of reformism stream by different analysis of political development issue. Here, the mentioned political development is the democratic mechanisms to make equal opportunities of reaching power for competitive groups and also the democratic law dominance which leads too civilized institutions growth. Meanwhile, there are various hypotheses, but the main hypothesis in this article is attention to this main question: "the theoretical weakness, lack of clarified strategy and inefficiency of reformisms stream, lack of internal coherence (the presence of contradictions inside reformists groups) that this article view is about the main and effective obstacles in reformist streams and political development in Iran after Jun, 23, 1997.

\section{Political Development}

The overall concept of development is "progress and spacious out". However, the conception of "political development", particularly from various attitudes and view are qualitative and structural view toward "political development". Some tried to count specific indexes and parameters for it by specific approaches. The theories of political development have various sequences and dimensions as theories of " classic development-oriented " was proposed in form of (a) quantity theory-oriented development (theory of behaviorism in the privatization of democracy, mobilization theory of Karl Deutsch and Daniel Lerner), (b) the development of the theory of functionalism, (c) development theory Shills oriented and (d) - the theory of crisis and those after him like Lucian Pyeand people after him such as Organski. In addition, Samuel Huntington by perceptions from institutionalism modernization and David Apter by newly developed functionalism analyzed political development.

It is noticeable that political development both in philosophical and sociological aspect depends on perception of "general field". The field the people can freely talk about their differences equally and freely about important political issues and their ideas transfer to the peak of political power pyramid. Strengthening such field is one of political development preconditions. In addition, it can be stated in general view that this issue is related to total political system, society and a country's cultural structure, and is with main reforms and evolutions in political, cultural, economic, and social structures. Actually, it needs to make principal mechanisms and legal tool and civilized institutions. Therefore, it is focused by scholars by various aspects and levels both content and structure of political and society systems. What in Mahmud Sari Alghalam view is "political development is the most complicated level of development for a society for being multi-aspect, comprehensive, and qualitative. (Sari Alghalam, 2001, p: 109)

Myron Weiner encompasses various ideas in political development and can be known as always controversial issue. (Weiner Huntington, 2000, p: 15)

According to many researchers, political development includes political methods and policies that softs economic growth in developing countries some other researchers defined political development as studying the new regulations, expanded the role of government, political participation and enhancing the regime's ability to maintain order in terms of accelerating and the competition between political groups, classes and ethnic groups compete for power and social status and wealth. According to some others, political development is how to occur revolutions, particularly alternation capitalist and socialist systems.

The best expression of political changes management theory finds it status about political development studies. Since in 1990s and 1950s, when political development was discussed, the maximum attention was focused on economic aspects of political development, because it was believed that the economic non-development is rooted from political structures inefficiency. However, related issues to policy and society that re called under the name of political development theories are in national and international discussion since Carthyism to Cold War that is particular product of specific vision in US society. Actually, the political sciences scholars attended more too political and social indexes and parameters more than economic factors since late 1960s.

Lucian Pye is one of significant scholars of political development with many discussions. He knows political development as successful transient period from six crises in book "aspects of political development": 1- identity 
Crisis 2- The crisis of legitimacy, 3- the crisis of influence,4.The crisis of participation, 5- the crisis of integration and unity, 6- the crisis of distribution (67-62 and Pye).

Leonard Binder expresses the concept of "political development" and cleans it from the concept of "social transformation". "The simplest way to make difference between applications of two terms to limit political development concept is to transient political results of a historical threshold" (Pye et al.) (Binder, 2001, pp. 43-42) In another summarized definition, the political development was defined this way. (Ali Babaei, 2003, p: 204)

Increasing the capacity and efficiency of a political system in resolving conflicts individual and collective interests, combination of popularity, freedom and fundamental changes in society, political development are with the growth of democracy. Three factors of organization, efficiency, practical ration, and leaders' ideological correlation have been known as installations of political development."

As it was stated, scholars have named many features and factors for developed political systems. Meanwhile, democratic and civil society symbols are as the third and independent field of government, it means organizations and non-governmental institutions. It should be mentioned that various political development definitions and conceptions are not necessarily determinant of dogmatic rule of various communities. Comprehensive experiences are different and specific in political development process, and social factors, economic, cultural, and political system of each community is influenced by these variables according to social value. Nonetheless, what is general in all communities in political development process is increasing movement and efficiency of community, limiting government power, increasing civil liberties and rights and in the final analysis, the strengthening of civil society.

It can be stated in spite of differences in various definitions of the developed and undeveloped (non-democratic) political systems, origin indexes and features of a developed political system (democratic) has less ambiguities such as main features that some theorists considered for such system such as Seymour Martin Lipset in the "Encyclopedia of Democracy". (List, 2004, p: 11- Dibacheh)

The first feature is competitiveness for the authentication public office, for the appointment of officials, fair elections, without the use of force or coercion and without any group in society is excluded or disadvantaged that are held in specific periods. The third feature is the presence of political and civil liberty to guarantee participation integration and precision and political competitiveness. Generally, according to this group of democracy support, important indexes such as strengthening civil society and the consequent civil and political freedom, popular sovereignty, civil rights, egalitarianism, rule of law and the rule of law, political participation, political parties, parliament and parliamentarism are the main and mutual elements of developed political system.

\subsection{Political Development before Islamic Revolution}

In contemporary era, the constitutional movement in Iran made the emergence of the components of the political development in Iran: parliament elections, political participation, limit the power of the king, parties, etc. are some of them if group activity from constitutional period started their activity first in the form of the "constitutionalist" and "authoritarian" and "revolutionary (later Democrat)" and "moderates".

After February, 21, 1921 coup, the parties emerged (socialist party, reform, modernization, etc.). It is noticeable to say that after the arrival of Reza Shah, Iran's political structure and dual authority had evolved that includes the central government and the tribal structure. "By evolutions in transformation, education, and administrative bureaucracy, Reza Shah changed the form and content of life, transformed social relations, and founded the principles of "modern state". (Miri, 2001, pp: 24-25)

The political structure of the first Pahlavi government had democratic political institutions and strong political groups and parties and wasn't effective; however, Reza Shah tried for innovation as Homayoun Katuzian believed. (Homayoun Katuzian. 2000, pp: 417-418).

"The fact was that he saved Iran from chaos and the modernization of the country with good results and bad step. According to analytical view, the reign of Reza Shah in the decade of the 1920 updated every few days more dictatorship was, still had not gone outside the framework of the constitution."

Actually, according to Katuzian belief, Reza Shah promoted both private and governmental economic activities (p: 449) by removing chaos, establishing peace and stability that itself was an effective precondition for development."

In the Second Pahlavi era, Mohammad Reza Shah had officially a constitutional monarchy form of government; 
it was based on the constitution of democratic institutions (Parliament, Cabinet, political parties etc.) and the separation of powers was also predicted. In initial years, it means 1941 to 1953 and the end of Dr. Mosadegh national government. Iran political space was more fractured and Shah Power was more limited, and parties were activated variously. However, in the second decade of Mohammad Reza Shah government, fragile and not very powerful political development elements were gradually faded and moved towards unilateralism and one-party political structure (the resurrection). Significant feature including negligence to political reforms and developments was the most important factors making people and other elites dissatisfaction.

Generally, political development is a process with direct relationship with dominated political system on society. Actually, political system is a framework in which political development occurred appropriate to its political capacity. Political development in modern political systems has more proper bed for growth. Nonetheless, all these systems don't provide similar forming conditions for it. Despotic states which are considered as the initial form of government system are the necessity of forming political system. In despotic states, totalitarian political power and space obstruction are necessary. Therefore, according to political sociology, Totalitarian with no formation of the political system and political development requires a direct connection is not functional review. Nonetheless, it should at least act according to internal political structure, base legitimate rights and operates within the framework of the agreed principle.

Iran political history, the despotic states were experiences in the first and second Pahlavi states. The performance examination of despotic governments of Reza Shah and Mohammad Reza Shah needs attention to governments according to political development perspective. The Pahlavi despotic governments did their main duty in evolving traditional systems, security, and also convergence, and national integration; nonetheless, these performances weren't legitimate during process.

Mohammad Reza Shah's government and state-building performance aborted political development process. Reza Shah made national integration and evolution in traditional arrangement by suppression of groups and social forces, not head the intellectual elite of society, excluded groups and civil society organizations, political repression, ethnic groups and tribes and blocking social space. Actually, Reza Shah Government performances in government-building process were based on power private state. Reza Shah removed social forces and oppressed ethnic groups and tribes for the purpose of the field in the socio-political competitors and neglected its state-building process, people, and political rights as the main base for policy development. Mohammad Reza Shah also put political power of government and semi-government project in his father way. However, in spite of at least completed an important part of this process, and it didn't need to complete totalitarianism in power, and preceded his father in despotic government and the denial of political rights. Personalization power in Mohammad Reza Shah era was more progressed and became a basis to deny political development. If Reza Shah denied political development by excuse of oppressing rebelled forces and also making national integration, Mohammad Reza Shah didn't have logical justification for it. In this era, evolution in traditional society and national integration was made to some extent. Therefore, the absolute negation of the state and political development fields did not found general acceptance.

Altogether, lack of political development in Pahlavi despotic governments not should be attributed to the nature of them, but it should be attributed to their despotic and personal political sovereignty. Nonetheless, according to political sociology, studying the relationship between none political development and government nature is true in Mohammad Reza Shah era. It is worthwhile to more study on Mohammad Reza Pahlavi than Reza Pahlavi since government-building process in the first era was done to great extent.

\subsection{Political Development after Islamic Revolution}

This ideology was represented after Islamic revolution and political- religious structural governance. Constitution of Islamic Republic of Iran was designed in such a way that (a combination of democratic on the one hand and religion - Shia on the other hand) in order to have different readings capacity. A number of key components of the political development in the law are anticipated, indicators such as the separation of powers, Parliament, political participation and elections, parties, free and independent press and some political and personal freedoms. Yet, according to ideological and political structure, there are combining the religious aspect with the general principles of law in all cases and the constitution.

It should be notices about one of the main components of political development as "political participation" that in the first decade after the revolution, political participation, expression and speech by Imam Khomeini (RA) and for mass participation or mobilization was manifested from that showed the presence of charismatic element in the power structure in Iran. In issue was predictable in that era (consolidation of revolution, war, etc.) and critical conditions; although basically the process of realization of the rule was stabilized based on their position. 
In this era and the end of war, the political participation is mainly under the influence of specific groups and as much possible opposition entered inside country. Later, government tries to institutionalized control by extensive presence in social affairs. Later, the supervisory approval law of Guardian Council was approved to supervise on various for state political eras. (Bashiriyeh, pp: 69-74)

Iran political era was free of all parties in the second decade after war. There was no free and independent press and political climate could lead to widening the gap between the people and the intellectuals' rules. As in late second decade of revolution and presidency of Hashemi Rafsanjani, a gape made between government and public, because many main related issues to people political life were neglected and such issues showed being influenced by political development principles in twenty-year period.

Actually, the evolutions in the first two decades after revolution provided reformism preconditions; though, groups and representatives of the movement were mainly the revolutionary forces and followers of the ideas of Imam Khomeini - the founder of the Islamic Republic - were modern but political slogans - social in particular the second decade of revolutionary values in the society and reactions provoked a lot of the government.

Generally, according to the proposed features, Iran political system after Islamic Republic can be in group of "ideological government". HosseiniBoshriyeh believed about such governments design and statement that "who can enter to power status in ideological governments that are faithful and committed to the ideology of competency criteria to join the group after the ruling, so the criterion of joining to trial group is relationship between faith and devotion. Ideological government in a general sense is religious and is principally encompassed with potential elements of the crisis of legitimacy, participation and what they have always wanted to put reforms. Some groups in the process of consolidation of power of the regime and the emergence of monopolistic tendencies are removed, constitute the political base of reform. (Bashiriyeh, 2010, pp. 185-189)

According to theoretical issues, it seems that the proposed reforms according to Iran Islamic system in June 1997 that was explained in the rest of article are mostly in framework of this theory. It is noticeable to say that constitution of the Islamic Republic of Iran is similar to any other constitution as the base of the game, and the birth of a democratic political system and measure its potential (political system). However, this law in spite of having democratic potentials have paradoxical face. Actually, Overlapping authority, lack of transparency and strong institutions in line with democratic structures (including the Guardian Council, etc.) have gotten the practical power of actualization democratic potential. As critics said a lot about it "Iranian law and the statements of the leaders of the Islamic Republic of Iran on political and social role of the individual have still large uncertainties in itself." (Yu, 2002, p: 209)

\section{Reformism Movement and Political Development}

Popularity of people toward slogans of reform movement (political development, freedom, civil society and the rule of law) can show a failure of the political structure of the first two decades of the revolution in serious movements towards political development. This is the movement that would stabilize the political system in turmoil after the war in 1978 and lost in eight-year war, and the dominated political space in this era, particularly at the end of war has long distance with people reformisms demand as the reason of revolution. This issue was explained by one of political activists (Behzad Nabaavi) explicitly. "It was also the slogan of the Islamic Republic, the "religious democracy" that Mr. Khatami proposed in the reform movement."

These two slogans were neglected for some reasons after victory of revolution. (Nabavi, p: 307)

The arrival of the seventh presidential election candidate Mohammad Khatami and acceptance of the New Left in the wake of efforts was perhaps a sign of their belief in the need to reform the country's political structure was at some level. A Khatami expressed his motivation as following as part of his official message to confirm the candidacy:

"We hope that proposing various and different views and provoking debate about them, in a privileged location presidential election, the political and intellectual vitality in the community is increasing and accelerate the power to choose and the people who own the country and the revolution. (Haghdar, 1999, p: 180)

Speeches of Mohammad Khatami can make this assumption that his presence in presidency polling was not on the predetermined and arranged planned, but was only to change the political climate superficially to reinforce democratic structures.

Yet, forming different political view in Iran after revolution as the second part of the revolutionary groups and product and effect of sociological has view of specific conditions of Iranian society in June, 1997 that showed people preparation to accept democratic conditions. Nearly a hundred-year history of the struggle for national sovereignty and constitutional democracy movement since 1953 and the Islamic Revolution has prepared Iranian 
for test despotism and political development.

\section{Reformism Thoughts Vectors}

As it was mentioned before, Oran unbalanced condition in June 1997 made panic of endangering the existence of political system and great crisis. In that time, anelite group that most of them were from the first rank of political power enacted people demands according to this issue and cognition the present conditions accurately, and the reformism ad reform thoughts was actualized in body and center if the resent discourses in Iran political spaces.

It seems that the main perspective of the main opposites as it was cleared in examining their minds. In addition to preventing a handy rule, power, new typeface in the community, providing a better reading of religion and eliminating the harsh face it: save the regime and the revolution and its ideals of damage, decay and oblivion are main objectives. Quoted by one of political activists (Behzad Nabavi) "the reformism slogans weren't initially idle or thee same as revolution slogans, an opportunity made in Jun 1997 that slogans were again explicitly proposed." (Nabavi, 308)

Therefore, according to idea of most reformists, Jun 1997 was the tail of Islamic revolution and reforms was actually attempt to accomplish the neglected slogans of Islamic revolution. However, the candidate, Mohammed Khatami didn't have discourse called "reformisms" initially and all was constitutional law, its execution, and legalism; as though, Seyed Mohammad Khatami said about it:

"If I want to say the most important element of 23 June, it is better I say among all different readings that: legalism is movement in constitutional law path; legalism means protecting religion and revolution from one hand and defending people rights and freedom from another hand; legalism means protecting justice accomplishment in society that the most significant aspect of justice is providing respect and security of all people one by one. (Khatami, 2001, p: 153)

This group which has supported the rule of law and democratic pro-reliance on legal authority and had seen everything in the constitution, called it as the final word. They mixed the anti-authoritarian discourse of constitutional law with general and democratic reading and hoped to execute some slogans.

However, it is noticeable to say that the resistance of some structures and influential groups in politics and the economy of Iran in practical aspect, and manner of religion and government dialectic, and finally the ratio of religion with modern concepts such as political development and civilized society in theoretical aspects are the most important issues of reformism government. As it is clear in texts and discourse $f$ designers, it actually tries to survive the democratic potentials of constitutional laws and tries to lean on it and reinforce civil institutionalism and political development, but Iran's space policy operation (according to the authority of the President) made the realization of these goals and the performance difficult. However, the idea of reform and the need for it was an issue that was looking at the seventh government.

Actually, reformism thoughts on some aspects versus rigid political structure were designer of the discursive features, more delicate, and more democratic discourse. In other words, the reformisms view tries hard to mixed the powerful centralized political space with religious sacred elements and remove it with its hard criticizing, moves it to realistic political era, and make conditions for the earthiness to reach sky of religious governments and remove these governments from line. Constant emphasis on human rights, the national sovereignty, self-determination, freedom, legality, struggle with insiders and outsiders thought for June 1997 all showed this issue. Having a reformism look and its main vectors, the similarities of Imam Khomeini thoughts can be observed in lighted form. Reformers refer to the revolution texts and the democratic polling of people, and democratic aspects of constitutional law to make evolutions. This issue is clear in their speech. Hajjarian explicitly stated this issue: "According to my idea, Imam Khomeini took long steps in this way and I think the breath of Islamic revolution and its establishment even if its name wasn't political development and not called democratization, was a project toward political development. It means if we want to scale it, Imam certainly promoted the indexes of democracy in Iran."

Mohammad Khatami says according to democracy spirit with a democratic conception of the constitution: "our constitutional law didn't want single voce population and wants freedom of thinking ad multiple voices. The spirit of constitutional law agrees on duplication and we have duty of considering it as the basis of our work." (Khatami, p: 43)

Khatami also has always been closely connected to religion besides elements of modern design and tells he never wanted to win one on another; although, the priority was always with religion. "Our system both want religion and to think to people liberty in light of religion. Confrontation with people liberty is weakening system. In addition, weakening the believing basis of society is weakness of system.” (Ibid, p: 95) 
The vector of reform-oriented thinking is "political development" in the alternative "religious democracy" that came with supplies and minutes. However, different trends shape the reform movement, each about the basic concepts related to democracy, sovereignty, and human rights, civil society, freedom, legality, competition and other parties had their own interpretations.

Legislation, civil society, individual freedom, civil rights, culture of dialogue, tolerance, merit, violence, modernity and updating of religious thought, paying special attention to women and youth, tolerance of dissenting views and ideas have the most important key factors and vectors of reformism thoughts which were always the words of Mohammad Khatami speeches and continuous in reformist groups literature. Mohammad Khatami says in his contract with who voted him:

"We have made a contract with you to the consolidation of society within the framework of our constitution and the rule of law as a vector of our duty. We are with you for the establishment and development of our comprehensive and lasting covenant. We have made a contract with you and with God as that to be defender of civil liberties and the legitimate rights and dignity of this noble nation and guardians of our nation and freedom. We have made a covenant with you, we move toward justice. We have made a covenant with you basic policy of détente as their relationship to follow the world and talk logically talk and preserve principles, we bring more credibility and facilities of the Islamic Republic. Today, I would repeat this entire covenant, and I reaffirm to you to go ahead everywhere any case the defense of the values, principles and defend, defend our security in a way that led to our great advances. (Ibid, p: 109)

Khatami's policy was very acceptable, particularly among students, youth, women, minorities and the new middle class, because he proposed an idea including factors such as legislation, individual freedom (or in fact, according to Khatami same respect for private life), strengthening civil institutionalized, equality and meritocracy, as well as in the field of foreign policy, calls for moderation and extensive international interactions. The reformists were aware of weaknesses in political democratic part of system (government and senate) in comparison to other system parts so tries to increase power and capacity of the state and strengthening mechanisms of political, social and economic development (at least in their slogans). One of political activists in referred to four points in definition of reformism movements.

1) The reform movement is still faithful to the ideals of the revolution

2) The Islamic Republic of Iran Islamic Republic of loyal course has two pillars; republicanism and Islamism.

3) Reformism movement believes that we must move in the framework of the constitution.

4) Reformism movement system of governance does not know the criticism is not criticism of the government. Changing the rule is not changing regime. Constitutional law is changing the governance from the highest level that has predicted each other in a system of periodic elections. (Yazdi, pp: 282-283)

Khatami entered rereading new Imam Khomeini's thoughts according to the conditions and time to the political arena and state management. According to Imam Khomeini, constitutional law of Islamic Republic of Iran has very high rank and was reference in most cases. People right and their participation, liberty in the framework of the constitution and canon law, and the prevention of corruption all were in Imam Khomeini Thoughts.

Mohammad Reza Tajik as another reformist described this type of thinking from "Khatami discourse" perspective and called as "Khatamism" interestingly:

I don't think by these terms, expressions and beliefs personal theories and trainings, but I mostly percept a practical-theoretical system which were tied around a specific elements and minutes of discourses which imply as "nodal points"." This nodal point according to my idea is "law" that minutes and elements of "civil society", "freedom", "democracy", "peaceful coexistence", "political competition rules", "political pluralism", "civil rights", "decentralization of power", "politics moral "," meritocracy " were arranged around it. (Iran newspaper, August 2, 2005, p:6)

Generally, the experience of the first two decades of the revolution and the Islamic Republic of mixing religion and government and private not-so-satisfactory results in the emergence of political, cultural, social and even economic have made the dependent religious scholars think in spite of this fact they religious political theory was implemented from the next day of March 31, 1978, and religious democracy was experienced (which was called Islamic Republic for nearly two decades. However, the Jun party proposed the summing democracy and religion with new form who proposed the necessity of reformat in political-social structure after revolution. They claimed that there were different readings of religion, this time they wanted to connect a particular form of religion (which have greater tolerance) to make democracy (even with his own kind of democracy). Significant advocates of religious democratic government, that knew combine diplomacy with a particular understanding of 
religion may be understood, usually believed that there is no contradiction between Islam and democracy. Actually, it can be stated that, according to Saeed Hajjarian idea, as the mastermind of the reform, "Total contrast is the relationship between religion and democracy, and the two do not match with each other totally; therefore, some forms of democracy can be added with some forms of religion" (Hajjarian, 2001, p: 131)

Mohammad Khatami, as the official rank of practical reforms, and the symbol and the slogan of political reform, with an emphasis on the constitution of the Islamic Republic of Iran and the foundations of the system proposed religious democracy by various ways as alternative and actually people felicity and survivals and tried to make it functional. In going toward the thesis of "religious democracy" he intensively believed on connection between policy and religion in the first step. (Khatami, 2000, pp: 36 and 37)

If you refer to Quran, you can see that a great group of orders in Quran can't be implemented without having a corresponded social system on Quran. It means if these orders were sent by God to be implemented, it means it is necessary to have religious government, religious society, and religious policy; otherwise, a great part of Quran trains stayed unused. In addition, if we refer to the beginning of Islam, no one can say that religion is separate from politics by looking to who lived in the time of Prophet Muhammad (PBUH) an their perceptions were adopted from trainings of prophet. As we move closer to prophet time, we can see that the unity between religion and politics increases. This is popularity and a consensus among Muslims that politics is part of religion and the religion of politics.

As it is understood from the mentioned texts, it seems that Khatami as a Muslim scholar with love of religion, and by the religion and the state in realistic clean and professional look to the question of politics and government, with esoteric considered priority for religion and the teachings and commandments; as politics in its Islamic definition and concept is regarded to guide community members toward the right path and treat faithful and committed people and also fight with oppression to establish justice in community. (Khatami, 2000, pp: 1999-2000)

Our society is a religious, and natural atheists claim that unreligious intellectuals didn't and don't have any place in this community and in people's hearts. Unfortunately, what has increased as enlightenment in new history of our county is face motion, unfounded and detached from the people. The voice of claimers of this state about opposition won't be heard from coffee shops and if heard won't be understood and consequently no understating would happen. If enlightenment has ever been anticipated was along with people religion and makes them close to their original religious beliefs. Here the secret of popularity of great people such as Al-Ahmad and Dr. Shariati can be understood in our dictator-ridden and humiliated society. The two were intellectuals and intellectual content, but the community feels that they are insiders and their pain and have people pain. The unreligious intellectual wants or doesn't, know or doesn't will help the enemies. The enemy that is opposite of our independence and fight with our original culture, religion, and liberty of these nation. Anyway, the mentioned text can be justified by Important elements of populism in the political culture of the Islamic Republic, especially coordination between populist tendencies and Shi'a traditions (in support of the poor and the oppressed masses and the emphasis is on people and the poor). Nonetheless, what favorite here is separated from valuation andcritique of Mohammad Khatami's beliefs, plans and basic expression of thought of him as the symbol of reform or democratic development o during the eight years of reforms?

\section{Pathology of Reformisms Stream}

Although, the intention of the reformisms hemispheres were attempts to determine and conceptualize the main issues (Political development, civil society, liberty and so on), no one (except the discourse of Abdolkarim Sorush about some conceptions even not so successful and researchable) acted seriously to determine and formulate the conceptions. They wanted all together by belief on connection among all factors and conceptions that had at least different roots and wills, but were unable in functionalizing the consensus in (religious democracy) and even scientific process. They couldn't solve the paradox among modern and traditional issues in the middle of political-social structure well. According to some reformists, there may be no contradictions among religious values and modern conception, but this is not accepted in view of many preset people in government and important part of traditional and spiritual spectrums of references don't accept it.

Although, reformism movement face with intensive reactions by powerful opposites from the first, reformisms party of Khatami didn't think to any act for this cases or not have the ability of any tact for it. Principally, the reformisms streams for their nature should have accurate and arranged plan to reach their goals. Although, people presence in voting of 1997 was not accidental and had many political-sociological roots, the formation of the reformist front and movements with message of the Jun month didn't have ancient background. This issue is described by one of reformists as following: 
"The condition of the Jun month was product of inevitable conditions after that date not the product of conscious and pre-determined decision making. The Jun, 22 front was made after revolution and it can be stated that it was imposed on June, 22 to get together and have close interaction with each other to tolerate hardships. This feature gives the sense of fragility to it and is present in varied spectrum of the second front of June 22. (Ghuchani, 2002, p: 36)

The Jun, 22 party didn't have clear and coherent flow and therefore no theoretical consensus., reformisms movement actually had problem in deepening its thoughts and had no integrated leadership and management, used its much power on oppressing the oppositions, and didn't have institutionalized (non-governmental) and extensive organizations to implement its plans.

Khatami as the representative of reformisms movement knew its advocate very varied; therefore, he escaped from more radical positions. Behzad Nabavi said in this regard: "the defect of Mr. Khatami like many reformists was that he thought if to be president can accomplish all reformisms slogans; therefore, he didn't prepared himself for leading the reformism movement"(Nabavi, p: 320) although, he tried a lot to reinforce parties, as Mohsen Mirdamadi, one of key members of participation party (the closest person to Mohammad Khatami) believe:

"Mr. Khatami at the beginning of election was in exceptional circumstances on June 76 that political could take a giant step forward for decades by making parties in the country. It means If Mr. Khatami came, and with all those who had supported him in the election formed the party and formally made the state party, a situation would be made that his opposite forces felt they need to make party. Therefore, they made party and country would change into two-party government. Maybe no one else has been in this situation since now, but Mr. Khatami concluded and didn't see it proper to limit himself in a party. I believe that if this happened, none of the harms that now reformism has experienced wouldn't happen for it." (Hammihan newspaper, Jun,30, 1997, p: 7)

It still seemed by these expressions that Mirdamadi knows the main reason of crisis of reformism party in Khatami performance. He certainly knows the lack of efficient structures as the main problem of reformism.

"The main problem of reformism era is lack of pervasivestructure. When the government and parliament were in hand of reformists, we didn't have the structure to be cited government and parliament, where important issues are examined and decisions made. In many cases, the effective forces in reformisms era weren't collaborated and think separately and decided, because they were not united. Anyway, Mr. Khatami preferred to move beyond parties and help to growth and development of parties. (Hammihan newspaper) According to our idea, the involvement of various cultural-cognitive factors, theoretical defects, theory crisis, and model in intellectual discourse and reformist, and no need effective organizations and neighbors are very important matters in their permanent non-success. Reformists tried to increase power sendgovernment capacity, then reinforcement social-economic mechanism with a low awareness of the weakness of the democratic political system (government) seeking disability in development programs. However, what power dies the Jun month party is given to proceed reformism and political development by controlled fields of Presidential Administration, the Cabinet, the legislature and the constitution as the final word and the rules of the game (especially in the eyes of reformers? How can we rely on the function of the press, political parties and civil society organizations to reach the goals? According to presence of very strong and stabilized that each one could play an important role in some parts and vital centers of reformism parties and they weren't faced with any challenges legally. Principally, the reformism parties in government by leaning on action field and authorities (even leaning on constitutional law) couldn't get the serious role of reformism in institutions and government key structures. Seyed Mohammad Khatami says in a version of the amendments pointed to the lack of understanding of the process of democracy and reforms some of its nine projects one year after ending the eight-year period:

"When I decided to participate in elections, I do not ... I was sure that the vote because it is natural that when I was president when we see a reaction, however, did not know some of these impacts may lead to misunderstandings between our inner being. We face a type of basic chaos with updating that was resulted from not having previous plans, while the president should decide moment to moment." (Javan newspaper, March 13, 2007, p2)

Generally, analyzing the mentioned texts and a type of anxiety and disruption clarifies not having mentality and practical plan. Theoretical challenges afflicting reformism streams included designs of using modern concepts which has mainly secular nature. The inability to effectively link these issues with religion and the lack of attention to system requirements and rules governing it are the most important problems of reformism which were related to internal factors of this movement. It can be claimed that according to postmodernism look, political development, democracy and religion can be as empty signifiers and signified are connected with many of the concepts, but such connection couldn't be made by reformists well in real and practical political field of 
Iran. Seyed Mohammad Khatami sometimes emphasized on the rule of law as the centerpiece of reforms (without regard to the question of whether the practice of the existing law means political reform) and sometimes political development and modern society as religious democratic in the form of religious democracy and dignity of leadership.

Hajjarian knows the happy, legal, and peaceful life peak in accomplishment political procedures of revolution and Imam Khomeini; however, the happy life according to whose perspective? What is the meaning of happiness? Each Iranian knows happiness as? Proposing these goals not only don't reduce its practical and theoretical value, but also seems as ordinary goals than an integrated and serious political plan. In other words, prominent members we so confused in determination goals and priorities. However, reformism thoughts were considered for new concepts in its design and the special atmosphere prevailing dissatisfaction with the status quo, after the hegemonic (dominant). We welcome the Iranian people to achieve their demands. Anyway, political development as the focus of reform thinking, in addition to structural challenges and the applicable law (outer barrier), within the reformist faction was never consensus and not operational systematic concept and definition and mechanisms, elements, and indexes were defined. In particular, issue of political development as religious democracy was mentioned by most reformists and such combination seems more necessary for being efficient, process, and theoretical engineering. As it was mentioned, the reformists' party and Mr. Mohammad Khatami didn't respect for hegemonic (dominant) and tried to prepare theoretical design (based on research and theoretic task|), macro and integrated program to proceed the unaccomplished reforms. They suddenly found the power in Iranian political storm stricken ship but couldn't resist against society demands against waves of young Iranian crisis and didn't have strong and effective measures, correlation, theory, and clear and transparent strategy. This made the era after eight-year of presidency to go toward where it went.

\section{Conclusion}

The discourse among reformists and development-oriented faced with failure in Iran for lack of efficient model, determined leadership relatively. Reform designerswere entered into the competition essentially without accurate and consistent program and the uncertainty of the seventh presidential election of June 1997; therefore, they didn't have manifesto (instructions), coherent and absolute strategy and theory. In other words, they don't have readiness to face with power to protect it. In the second period of Mr. Khatami presidency, a type of frustration, confusion and incremental disorganization was seen in reform party; regarding to this fact Mr. Khatami entered to presidency with a type of hesitate. In this period, reformists more thought to the end of reformism period instead of trying to find their weaknesses to cope with dominant structural challenges, society, and plans.

Following such issues, a gap made among people, groups and pro-reform (including the student movement) and the State reform because of dissatisfaction with the performance of reformers. The gap among people and reformists was for dissatisfaction from reformists' performances. This gap made distrust on the reformism body.

Khatami couldn't play a role of an integrator of power as the main symbol of reformism among the advocates parties for not having party-political structures since his relationship with some important opposite organizations to reformism was so close. Now, management of this project (political reformism|) should have been strong, integrating, and powerful, because the proposed demands and slogan while reformism process with Iranian support and movement should have been implemented somewhere by type of management. Undoubtedly, accomplishing such goals (in such dominant ideological system) needed certain and précised planning and mechanisms including:

1) Having specific, efficient, and integrated theory, charter, and plans;

2) Consensus about the theory and mutual charter;

3) Protecting internal coherence and unity in the party and maintaining regular and continuous link with the community;

4) Having transparent and efficient strategies and technics in various sections;

5) Having strong organization and structures;

Generally, it can be concluded that the attributed party to Jun 1997, that made an extensive spectrum, had many perspectives and ideas followed varied gals ad strategies. The incremental confusion and conflict in many cases were resulted from this issue among members of this party and other issues such as role, status, and leadership performance of movement (Mr. Khatami).

\section{References}

Ali Babaei, Gh. (2003). political culture Arash. Tehran: Publication Ashian. 
Badie, \& Bertrand. (2001). Development politique (3th ed.).

Bashiriyeh, H. (1999). Political participation and election crisis in June 1997. In A. Rezaei \& A. Abdi (Eds.), $a$ new election (sociological analysis of the events of June). Tehran: Tarh-e No.

Bashiriyeh, H. (2005). History of political sociology of the Islamic Republic of Iran. Tehran, contemporary look.

Ghuchani, M. (2002). the older brother is dead, the reform in agony. Tehran: Nagh-o-Negar.

Haghdari, A. A. (1999). Political and cultural discourse Khatami. Tehran: Shafiei.

Hajarian, S. (2000). Pay reform (Proceedings). Tehran: Publishing and Research Institute Zekr.

Hajarian, S. (2001). from witness to witness the sacred market (secularization in the sphere of politics). Tehran: Tarh-e No

Hammihan Newspaper, interview with M., Mirdamadi, No. 14 New Era, May 28, (2007), p. 6.

Javan Newspaper, No. 2267, March (2006), p: 2.

Katuzian, H., \& Ali, M. (2000). State and Society in Iran: the extinction of the Qajar and Pahlavi establishment, translated by Hassan Afshar. Tehran: Markaz Publishing.

Khatami, M. (1380). Democracy. Tehran: Tarh-e No.

Khatami, M. (1997). wave beam (Proceedings). Tehran: Young Broadcasting Institute.

Khatami, M. (2000). Muslim clerics and Islamic Revolution. Tehran: Tarh-e No.

Lucian, P. (1971). Crises and Sequences in Political development.

Miri, A. (2001). the history of the culture of despotism in Iran. Tehran: Tarh-e Moaser.

Moein, M. (1985). Persian Culture (Vol. I). Tehran: Amir Kabir.

Newspapers (Special presidency of Mohammad Khatami), an interview with M.R., Tajik, No. 3209, August 2, (2005), p: 6 .

Py, L. (1996). Aspects of Political development. Boston :little Beown and company.

Sariolghalam, M. (2003). Rationality and the future of Iran's development. Tehran, center for scientific research and middle Eaet strategic studies.

Siyung, U. D. (2002). political culture and political development: comparative studies on Korea and Iran. Tehran: KhaneSabz.

Yazdi, A. E. Y. (2001). the reform movement, goals and needs. In M. Ghani, \& N. Mohammadi (Eds.), reform strategy, a tactic: a collection of women speeches expressed in the Islamic Revolution. Tehran: Saraeei.

\section{Copyrights}

Copyright for this article is retained by the author(s), with first publication rights granted to the journal.

This is an open-access article distributed under the terms and conditions of the Creative Commons Attribution license (http://creativecommons.org/licenses/by/4.0/). 